\title{
Milnacipran for the Treatment of Fibromyalgia
}

\author{
Harshit Gupta, BSA', Brook Girma, MD², Jack S. Jenkins, BS², Sarah E. Kaufman, MS², Christopher A. Lee, MD ${ }^{3}$, Alan D. \\ Kaye, MD, PhD ${ }^{2}$ \\ 1 David Geffen School of Medicine, University of California Los Angeles, ${ }^{2}$ Department of Anesthesiology, Louisiana State University Shreveport, 3 \\ Department of Internal Medicine, Creighton University School of Medicine-Phoenix Regional Campus \\ Keywords: ssri/snri, fibromyalgia, savella, milnacipran \\ https://doi.org/10.52965/001c.25532
}

\section{Health Psychology Research}

Vol. 9, Issue 1, 2021

\section{Purpose of review}

This is a comprehensive review of the literature regarding the use of milnacipran in treating fibromyalgia. A chronic pain disorder with other system disturbances, fibromyalgia is often resistant to many therapeutic approaches. This review presents the background, evidence, and indications for using milnacipran as a treatment option for this condition.

\section{Recent Findings}

The definition of fibromyalgia has evolved over many years as it is a relatively tricky syndrome to measure objectively. Today, it is characterized by chronic, widespread pain accompanied by alterations in sleep, mood, and other behavioral aspects. A variety of therapeutic regimens currently used to treat the syndrome as a singular approach are rarely effective.

Milnacipran is one of three drugs currently approved by the FDA for the treatment of fibromyalgia. It acts as a serotonin and norepinephrine reuptake inhibitor, which results in decreased pain transmission. Milnacipran remains an effective treatment option for fibromyalgia in adults and needs to be further evaluated with existing therapeutic approaches.

\section{Summary \\ Fibromyalgia is a broad-spectrum disorder primarily characterized by chronic pain coupled with disturbances in cognitive functioning and sleep. The progression of this syndrome is often debilitating and significantly affects the quality of life. Milnacipran is one of three FDA-approved drugs used to alleviate the symptom burden and is comparatively more therapeutic in specific domains of fibromyalgia. A more holistic approach is needed to treat fibromyalgia effectively and further research, including direct comparison studies, should be conducted to fully evaluate the usefulness of this drug.}

\section{INTRODUCTION}

For several centuries, fibromyalgia (FM) was thought to have been a clinical entity related to rheumatism until the foundation was laid, revealing FM to be instead a somatic syndrome or part of a somatization disorder. FM is clinically challenging to characterize with typical lab values and a lack of identifying biomarkers. ${ }^{1}$ For many years, this disor- der has been widely criticized and unaccepted due to its lack of pathophysiologic findings. In 1990, a large multi-center study was performed to develop criteria for diagnosis of FM, which ultimately led to the development of the American College of Rheumatology (ACR) 1990 criteria classification for FM diagnosis. Today, FM is characterized as a syndrome involving widespread muscle pain and tenderness, involving multiple joints, often accompanied by symptoms of al-

\footnotetext{
a Corresponding author:

Christopher Lee, MD

St. Joseph Hospital \& Medical Center

Department of Internal Medicine

500 West Thomas Rd

Phoenix, AZ 85013

Chrislee0621@gmail.com
} 
tered mood, cognition, and or fatigue. The ACR 1990 classification describes widespread pain as tender points in 3 sites and is typically tested clinically by palpation or dolorimetry. This classification was revised in 2010 and 2011, followed by a revision in 2016. The 2016 criteria now require that patients have pain in 4 of 5 regions, called "generalized pain" to distinguish it from the 1990 definition of "widespread pain." ${ }^{2}$ FM is frequently accompanied by other conditions such as irritable bowel syndrome, headache, fever, diarrhea, oral ulcers, dry eyes, vomit, constipation, skin rash, hearing difficulties, hair loss, painful and frequent urination, etc. ${ }^{3}$ Although inflammatory, infectious, and autoimmune disorders have all been ascribed to be etiological events in the development of fibromyalgia, there is very little data to support such a thesis. ${ }^{4}$

Milnacipran is one of three FDA-approved medications for fibromyalgia syndrome (FM) and has proven to be effective and recommended as first-line therapy for fibromyalgia. Initial management may have involved the use of opiates, which led to concerns about dependence. In the late 20th century, it was revealed that serotonergic and norepinephrine drugs effectively managed fibromyalgia, resulting in their incorporation for the therapeutic approach to FM. The focus of treatment also includes education, patient support, physical therapy, nutrition, and exercise to improve quality of life. Patients with significant debilitation or with sleep disturbance may require medical treatment. Milnacipran is characterized as an SNRI because in vitro studies have shown that milnacipran has a three-fold greater efficacy for inhibiting norepinephrine reuptake than serotonin, which differentiates it from the SNRIs, which are more serotonin active. ${ }^{5}$ These neurotransmitters have been a focus for the treatment of FM as they have been shown to have properties allowing significant modulatory effects on central and peripheral pain processing. Milnacipran has proven to be a promising medication in FM management and will be discussed further throughout this article.

\section{EPIDEMIOLOGY}

Numerous epidemiologic studies have been performed analyzing characterization and profiles of FM. Still, most have concluded FM to be idiopathic and related mainly to an aggregation of environmental, behavioral, and possibly genetic factors. Depending on the diagnostic criteria used, the prevalence is from $2 \%$ to $8 \% .^{6}$ It is considered multifactorial and combines genetic and epigenetic factors that determine a persistent dysfunction in pain regulation systems and central nociceptive hyperexcitability along with a decreased inhibitory response activity related to pain modulation and control. ${ }^{7}$ The global prevalence of FM, in 26 studies worldwide, is $2.7 \%$ and is more prevalent in women, in patients over 50 years of age, in subjects with low education level, with low socioeconomic status, living in rural areas, and possibly in obese women. ${ }^{8}$ Several studies have also linked FM to patients with multiple comorbidities and increase the burden affecting patient outcomes. This also makes it difficult to detect or diagnose, as there is overlap in symptomology. FM has shown to be a significant hardship, socially, economically, physically, and psychologically. Identifying the epidemiology of this disorder has been es- pecially difficult, as it requires specialists to diagnose it as rheumatologists primarily diagnose it today. With the help of the expanding healthcare databases provided by electronic recording, more studies need to be conducted to understand FM better and develop a concrete epidemiological profile.

\section{IMPACT AND BURDEN}

FM has been frequently associated with significant burden and several comorbidities, whether physical or psychological. Some studies have also shown FM negatively impacts the socioeconomic level affecting patients' ability to fulfill activities of daily living, work or home responsibilities, and even their sexual health not only due to pain but also fatigue and associated comorbidities. The lack of ability to perform daily activities tends to cause an increase in BMI for FM patients as their symptoms prevent most physical activities and promote a sedentary lifestyle. In addition, FM patients tend to experience high levels of stress, anger (including anger-in or anger suppression, anger-out or anger expression, and angry rumination), and pain catastrophizing (conceptualized as an exaggerated negative orientation to pain, which provokes fear and discomfort and increases pain perception), which are frequently associated with a worsening of symptoms, including cognitive ones. ${ }^{8}$ One study performed in the Netherlands highlighted and explored the impact on the patient's quality of life and psychological distress caused by FM compared to those with other chronic pain syndromes by utilizing various questionnaires, scales, and checklists. Overall, this study concluded that FM patients had higher psychological distress and a lower quality of life, usually coinciding with their level of disability. Compared with patients with rheumatoid arthritis, especially the mental health and social functioning of patients with fibromyalgia seem to be more affected. ${ }^{9} \mathrm{FM}$ is associated with high socioeconomic costs for the health system (medical visits, specialized consultations, diagnostic tests, drugs, and others therapies) and the workforce (sick leave, high rate of absenteeism, and decreased workrelated productivity). ${ }^{3}$

\section{PATHOPHYSIOLOGY}

The primary symptom of FM is described as widespread pain with abnormal pain-sensitive sensitivity. It is seen to be caused by several variables: abnormalities in the central nervous system or neuroendocrine pathways, genetics, socioeconomic status, and psychological triggers. FM patients are noted to have an increased sensitivity to cold and painful stimuli, and irregularities in the central nervous system play a role in decreased inhibition of these stimuli. With these stimuli, an increase in stress is seen, causing derangements in the hypothalamic-pituitary-adrenal (HPA) axis, further exacerbating symptoms and leading to other comorbidities. Some studies have also suggested a genetic component when examining the relationship between FM patients with first-order relatives with rheumatologic pain disorders. Results from several investigations indicate that a single nucleotide polymorphism (SNP) in the serotonin 
transporter (5-HTT) gene may contribute to enhanced pain sensitivity in patients with fibromyalgia and other affective spectrum disorders. ${ }^{10}$ Other investigations have shown a possible relation to catechol-O-methyltransferase (COMT) gene variants and the dopamine $\mathrm{D} 4$ receptor (DRD4) gene. Other areas of interest include environmental triggers such as exposure to physical or sexual abuse and psychosocial stressors. With further studies, understanding the different components of FM can lead to other therapies and provided a foundation for current therapies approved today.

\section{RISK FACTORS}

A review of 37 papers by Creed illustrated the most common risk factors for FM. Risk factors included various childhood difficulties, female sex (except with pre-existing medical disorders), older/middle age, smoking, high body mass index, alcohol abstinence, and pre-existing medical diseases in adulthood. ${ }^{11} \mathrm{FM}$ has been noted to be multifactorial, and some studies state it may have a genetic or socioeconomic component involved in developing this chronic syndrome. Some other factors seem to predispose individuals to FM, such as accidents (traffic and work injuries, fractures, polytraumatisms), medical interventions and complications (such as from surgeries and infections), and emotional traumas (sexual and physical abuse and neglect). ${ }^{3}$ One central result of the Imbierowicz et al. study showed that traumatic experiences, such as physical and sexual abuse during childhood, tend to lead to emotional and physical symptoms predisposing to FM. Also, insufficiently supportive relationships with the primary caregivers, a poor emotional relationship and a low-level feeling of security, poor physical care, as well as experiences of physical or sexual violence all characterize the biography of these patients. ${ }^{12}$ With all the data gathered on the given risk factors, future studies could place a focus instead on the mechanisms relating to these risk factors for prevention.

\section{DIAGNOSIS AND CLINICAL PRESENTATION}

Today, several diagnostic and screening criteria exist and have been developed over the years. Given the multifactorial nature of the FM, there continues to be a need to establish criteria that reflect the pain syndrome clearly and provide a practical approach to the diagnosis of FM. The ACR 1990 classification provided the framework for advancing clinical studies. Still, it was difficult to use in a clinical setting, as it was impractical to utilize the tender point exam due to bias. Some required specific signs or expressions to accommodate palpation of the tender point, while other required acknowledgment of pain alone. Later, the US Food and Drug Administration (FDA) and the American Pain Society (APS), to establish a clinically useful and consistent diagnostic system for FM, created the ACTION-APS Pain Taxonomy (AAPT). This diagnostic classification system focused on identifying core symptoms of FM and allowing the addition of associated symptoms, which provided a multidimensional approach to the diagnosis of FM.

In the AAPT taxonomy, there are five dimensions: 1) core diagnostic criteria; 2) common features; 3) common med- ical comorbidities; 4) neurobiological, psychosocial, and functional consequences; and 5) putative neurobiological and psychosocial mechanisms, risk factors, and protective factors. ${ }^{2}$ With this new approach provides the framework to improve the diagnosis of FM and highlights the relationship between FM and stress exposure and other clinically significant comorbidities.

\section{CURRENT TREATMENT OF FIBROMYALGIA}

Fibromyalgia (FM) is a pain syndrome characterized by a plethora of multisystem insults. Overall, the main symptom is chronic generalized pain linked to psychological, cognitive, and behavioral disturbances. Stress, sleep disturbances, and mood disorders are just to name a few. In the US, there are only three FDA-approved treatments for FM. ${ }^{13}$ The three FDA drugs are pregabalin, duloxetine, and milnacipran. In addition to these treatments, multiple other pharmacological and nonpharmacological therapies exist that are still being tested. An emerging field of pharmacological treatments is in the cannabinoid and opioid fields. In addition, genetics and an increased understanding of complex CNS disorders will likely be vital to appreciating the complexities of FM. ${ }^{13}$ Common nonpharmacological modalities include exercise, mind and body, and acupuncture ${ }^{14} \mathrm{~A}$ diagnosis of FM consists of a lifelong battle with chronic pain and other insults that pose a significant burden to our healthcare system and economy. Over the past two decades, we have redefined our understanding of FM as a broad-spectrum disorder instead of a single condition. ${ }^{14}$ It is ever so important to treat a broad-spectrum disease with a multidisciplinary approach using pharmacological and nonpharmacological treatments. A more holistic approach and starting treatment with education on FM, the various therapy, and incorporation of multiple treatment outlets is vital. 14

\section{PREGABALIN}

Part of the gabapentinoid family, pregabalin is a current FDA-approved medication for chronic pain in FM. This family of drugs acts at the alpha2delta subunit of voltage-gated calcium channels in the CNS. ${ }^{13}$ In a meta-analysis of randomized controlled trials, gabapentin, and pregabalin, demonstrated strong evidence of reduced pain, increased sleep, overall improved health, and quality of life, but was not beneficial for depressed mood. ${ }^{15}$

\section{DULOXETINE}

Duloxetine is an FDA-approved serotonin-noradrenaline reuptake inhibitor. This family of drugs acts by preventing serotonin and noradrenaline reuptake, important neurotransmitters, in the brain. A meta-analysis of duloxetine and milnacipran demonstrated a significant reduction in pain and increased patients' perception of pain improvement. ${ }^{14,16}$

\section{NALTREXONE}

One of the descending pain inhibitory pathways mediated 
by opioids is relevant in FM. ${ }^{17}$ Naltrexone is a competitive opioid receptor antagonist demonstrating a positive effect on FM and reducing pain with associated depression. ${ }^{18,19}$ Naltrexone is also indicated in an anti-inflammatory pathway. It plays a role in decreasing activated microglia cells in the stimulation of the neuroinflammatory processes. ${ }^{13}$ The inhibition effect produced by naltrexone proved beneficial and provided pain-relieving properties. ${ }^{19}$ Most of the time, opioids are only selected for the most extreme cases of FM and only for a very short period. ${ }^{20}$

\section{CANNABINOIDS}

The Canadian guidelines for treating FM have already incorporated cannabinoids for therapy. ${ }^{13}$ Cannabinoids consist mainly of the two active components, tetrahydrocannabinol (THC) and cannabidiol (CBD), respectively. Generally, the ratio of these two components determines the effectiveness and overall function of the drug. It is hypothesized that an absence of endocannabinoid activity disrupts the complex system of pain modulation and incites FM. ${ }^{21}$ Studies comparing nabilone and dronabinol have not yet been conclusive. Researchers are aware that varying the ratio of THC:CBD components affects FM patients differently. The THC component improved the pain tolerance and the CBD component increased plasma-THC but decreased its ability to relieve pain. ${ }^{13}$ The endocannabinoid field has the potential to prove itself in the near future.

\section{DOPAMINE RECEPTOR AGONISTS}

Various attempts at modifying the dopaminergic pathways for the treatment of FM have been tested. Tergulide, a dopaminergic agonist, was found to improve FM symptoms in patients with spinal stenosis. ${ }^{22}$ In addition, other metaanalyses have demonstrated dopaminergic agonists were not recommended, did not improve quality of life, and added unwanted side effects such as sleeping difficulty and nausea. ${ }^{23}$ Due to consensus among researchers and adverse effects, dopaminergic agents are not FDA approved in the United States.

\section{TCAS}

Tricyclic Antidepressants were commonly used for depression in the past but are currently used for various types of chronic pain. They are not without side effects. Amitriptyline is the TCA of choice for FM. It has been found to improve overall pain, sleep, and quality of life. ${ }^{24}$

\section{MILNACIPRAN}

Similar to duloxetine, milnacipran is another serotonin-noradrenaline reuptake inhibitor approved by the FDA for FM treatment. Milnacipran has been shown to improve pain and fatigue levels in patients with FM but can cause sleep problems and depressive symptoms. ${ }^{14}$ Milnacipran has a clinical benefit of improving $30 \%$ or more significant pain relief but not for $50 \%$ or greater. ${ }^{25}$

\section{MILNACIPRAN DRUG INFO}

\section{INDICATIONS AND USAGE}

Savella (milnacipran $\mathrm{HCl}$ ) is a selective serotonin and norepinephrine reuptake inhibitor (SNRI) initially approved in 2009 to treat fibromyalgia. ${ }^{26}$ It is not approved for pediatric patients and is only available by prescription. It is only approved for adults 18 years and older. ${ }^{26}$ Milnacipran is intended to reduce pain levels, improve fibromyalgia, and ease physical activity. It can cause suicidal thoughts and ideations in some participants. Importantly, it is not used to treat depression and psychiatric conditions, but its mechanism of action is very similar to antidepressant medications. Milnacipran should never be taken with a monoamine oxidase inhibitor (MAOI) as it could cause potentially lifethreatening side effects. ${ }^{26}$

\section{DOSAGE AND STRENGTH}

Milnacipran should be administered in two divided doses per day. The general titration table goes as follows: day 1: $12.5 \mathrm{mg}$ once, days 2-3: $25 \mathrm{mg} /$ day (12.5 mg twice daily), Day 4-7: $50 \mathrm{mg} /$ day (50 mg twice daily), Day 7, and after 100 $\mathrm{mg} /$ day (50 mg twice daily). ${ }^{26}$ With that being said, the recommended dosage of $100 \mathrm{mg}$ (50 mg twice daily) can be increased up to $200 \mathrm{mg}$ /day depending on the individual patient. $^{26}$ The Savella tablets come in $12.5 \mathrm{mg}, 25 \mathrm{mg}, 50 \mathrm{mg}$, and $100 \mathrm{mg}$ tablets.

\section{CONTRAINDICATIONS}

Milnacipran might cause serotonin syndrome, and patients should have regular checkups and be monitored for safety concerns. MAOI used to treat various psychiatric conditions should not be combined with milnacipran treatment. MAOI should not be used with milnacipran or within five days of stopping treatment. ${ }^{26}$ Milnacipran should not be used within 14 days of quitting an MAOI medication. Also, Savella is not to be combined with linezolid or IV methylene blue. ${ }^{26}$

\section{WARNING AND PRECAUTIONS}

Milnacipran may worsen suicide risk and even depression. Serotonin syndrome has also been reported with Savella alone and in combination with other serotonergic agents. Savella is known to elevate blood pressure, and each patient should be evaluated before, during, and after treatment. ${ }^{26}$ Take caution when prescribing Savella to patients with a history of seizures. Similarly, this treatment should be taken with caution in those with a history of liver disease or chronic alcohol intake. Instead of stopping the medicine immediately, Savella should be slowly titrated out of the patient. ${ }^{26}$

\section{ADVERSE SIDE EFFECTS}

Nausea, headache, constipation, dizziness, insomnia, hot flush, hyperhidrosis, vomiting, palpitations, increased heart rate, dry mouth, and hypertension are all adverse side effects of Savella treatment. ${ }^{26}$ 


\section{MECHANISM OF ACTION}

Milnacipran belongs to the serotonin and norepinephrine reuptake inhibitor class of drugs. It is commonly used today as an antidepressant but notably does not affect neurotransmitter levels analogous to the tricyclic antidepressant of the past. ${ }^{27}$ Most SNRIs do not exhibit an equipotent reuptake inhibition to SE and NE and a linear dose-concentration trend. ${ }^{28}$ Milnacipran is highly advantageous for FM therapy as it does not interrupt the cytochrome P450 enzymes for drug metabolism. In mice studies, milnacipran has been shown to stimulate clonidine-aggressiveness in mice and activate the overexpression of alpha1-adrenoreceptor. ${ }^{29}$ After continued exposure to treatment with milnacipran showed unresponsiveness of the 5HT2A receptors with their agonists and downregulation of the 5HT2A system. ${ }^{29}$ For neurotransmitter receptors, it has been concluded that milnacipran does not show these neurological changes certainly in the alpha1-adrenergic and 5HT2A pathways. $^{29}$

The ability of milnacipran to modify to 5HTA1 autoreceptors and postsynaptic 5HTA1 receptors has been elucidated in rats. As seen in an electrophysiological recording of the dorsal raphe nucleus, serotonin blocks the 5HT1A receptor antagonism. ${ }^{27}$ Milnacipran only slightly knocked down the firing of the 5-HT system upon three days of administration but significantly did after 7 or 14 days of treatment. ${ }^{27}$ Milnacipran also decreased the potency of the 5HT system, unlike similar tricyclic antidepressants such as imipramine. ${ }^{27}$ The CA1 potential in hippocampal slices of these rats were unchanged; therefore, milnacipran was demonstrated to deaden the somatodendritic 5HT1A receptors as opposed to the postsynaptic receptors. ${ }^{27}$

The activity of the dorsal raphe neurons and locus coeruleus neurons can be measured in chloral hydrate anesthetized rats. ${ }^{30}$ Extracellular unitary recordings can measure the activity. First of all, through 2,7, and 14-day treatments of milnacipran significantly tuned down the activity of NE neurons. ${ }^{30}$ The total level of NE is unaffected but by the alpha2-adrenergic effects. Following a similar treatment regimen with milnacipran, serotonin (SE) activity completely recovered by 14 days. ${ }^{30}$ Norepinephrine (NE) uptake in the hippocampal areas was decreased but not SE uptake. Through further studies in NE-denervated mice, milnacipran did not affect the dorsal raphe nucleus. ${ }^{30}$ Milnacipran allows SE recovery by some mechanism related to NE neurons.

\section{PHARMACOKINETICS/PHARMACODYNAMICS}

As mentioned, milnacipran is a versatile drug due to its ability to block both the norepinephrine and serotonin reuptake system in vitro and in vivo. It has thus been called a dual-action antidepressant. ${ }^{31}$ The pharmacokinetic profile consists of a high degree of absorption and utilization, high free plasma binding, and a short elimination half-life. ${ }^{32}$ Milnacipran is a favorable treatment for FM due to the lack of potential adverse drug interactions. It has been demonstrated that there is no affinity to other neurotransmitters in the postsynaptic adrenergic, muscarinic, and histamine receptors. ${ }^{31}$

In comparison to tricyclic antidepressants, milnacipran does harm cognitive function and psychomotor function. In clinical trials, milnacipran dose of $100 \mathrm{mg}$ in young adults and up to $75 \mathrm{mg}$ in elderly patients is devoid of cognitive and psychomotor performance disruption. ${ }^{32}$ With the same two groups of patients, the tricyclic antidepressant amitriptyline did significantly disrupt patients in the numerous cognitive and psychomotor tests. ${ }^{32}$

Other clinical trials have shown the milnacipran must be adjusted based on the condition of the kidneys. Based on renal impairment, mild impairment requires no dose adjustment. ${ }^{33}$ With moderate and severe renal impairment, the dose should be used with caution and a 50\% maintenance reduction for the latter. ${ }^{26}$ Milnacipran is not recommended for end-stage renal disease. ${ }^{33}$

Some clinical trials have looked at the hepatic impairments and effects on milnacipran. Milnacipran was shown to have high bioavailability, with the majority excreted in the urine without conjugation and about a tenth as a glycoconjugate. ${ }^{34}$ The liver impaired patients did not see a significant change in the pharmacokinetics upon milnacipran administration. ${ }^{34}$ Due to the negligible effects on drug metabolism, milnacipran has minimal drug interactions and can be combined with other medications. ${ }^{34}$ There is a low impact on the cytochrome p450 systems, which is advantageous for a drug designed to treat FM. FM is challenging to treat due to its multisystem insults; therefore, successful medication like milnacipran must have an excellent drug profile and work in junction with other treatments.

\section{CLINICAL SAFETY AND EFFICACY}

Multiple randomized, double-blind controlled trials of milnacipran show it efficacious in treating fibromyalgia and generally well-tolerated by patients. The most common side effects of milnacipran appear to be nausea and headache. Some studies found the risk of adverse events with milnacipran not to be significantly higher than the risks associated with other medications approved for the treatment of fibromyalgia. Additionally, long-term studies up to three years in duration found that milnacipran continues to be effective for the symptoms of fibromyalgia, with over $70 \%$ of patients rating their overall symptoms as "much improved" or "very much improved" at the 3-year endpoint. ${ }^{35}$ Milnacipran does carry a boxed warning for increased suicidal thinking and behavior in children, adolescents, and young adults. However, it is not approved for use in pediatric patients. It also carries a warning for increased blood pressure, and evidence suggests that the mean increase in systolic and diastolic blood pressure is around $4-6 \mathrm{mmHg} .{ }^{36}$ Several studies and multi-study reviews have shown no significant prolongation of QTc compared to placebo at and above the recommended dosing amounts. 37,38

In a randomized, double-blind, placebo-controlled trial of milnacipran vs. placebo for fibromyalgia, patients were randomized to placebo, milnacipran $100 \mathrm{mg} /$ day, or milnacipran $200 \mathrm{mg} /$ day and treated with a fixed dose for 27 weeks. The patients' response to therapy was classified using a 24-hour morning recall of pain collected daily via electronic diary, the Patient Global Impression of Change 
(PGIC), and the Medical Outcome Study Short Form 36 Physical Component Summary (SF-36 PCS). ${ }^{39}$ Of the 888 patients randomized in this study, 186 discontinued due to adverse effects - 23 in the placebo group (10.3\%), 44 in the milnacipran $100 \mathrm{mg} /$ day group (19.6\%), and 119 in the milnacipran $200 \mathrm{mg} /$ day group (27.0\%). ${ }^{39}$ The second most common reason for withdrawal from the trial in the active arms of the study was a therapeutic failure $(100 \mathrm{mg} /$ day - 26 patients, $11.6 \%$; 200mg/day - 49 patients, $11.1 \%$ ), and it was the most common reason for discontinuation in the placebo group (34 patients, 15.2\%). Both groups receiving active medication showed significant improvement in fibromyalgia symptoms of pain ( $p<0.05$ across all measures), fatigue $(p=0.016)$, and cognition $(p=0.025)$, as well as on multiple SF-36 domains. ${ }^{39}$ The study authors noted that pain was significantly reduced in the active arms compared to placebo as early as week one. Maximal pain reduction was achieved by week nine and maintained through the rest of the study period. PGIC scores were significantly improved in both the $100 \mathrm{mg} /$ day and $200 \mathrm{mg} /$ day milnacipran arms when compared to placebo at week $15(\mathrm{p}=0.009, \mathrm{p}<$ 0.001 , respectively), and remained significant through week 27 ( $p<0.001) .{ }^{39}$ The medication was generally well-tolerated by the patients in this study; nausea and palpitations were the only symptoms that caused study withdrawal rates $>2 \%$ and of greater incidence in the study groups $(100 \mathrm{mg} /$ day $-32.6 \% ; 200 \mathrm{mg} /$ day $-40.1 \%$ ) than in the placebo group (21.1\%). ${ }^{39}$ If participants did not discontinue the medication, nausea typically resolved within 1-2 weeks. Three serious adverse events were judged to be related to the study medication, including exercise-induced intermittent rapid heart rate and chest pain, chest discomfort, and nausea. Still, overall rates of serious adverse events did not significantly differ between the placebo, $100 \mathrm{mg} /$ day, and $200 \mathrm{mg} /$ day groups $\left(2.7 \%, 1.3 \%\right.$, and $2.5 \%$, respectively). ${ }^{39}$ Clinically significant increases in systolic blood pressure (SBP, defined as $\geqslant 180 \mathrm{mmHg}$ with an increase of $\geqslant 20 \mathrm{mmHg}$ from baseline) and diastolic blood pressure (DBP, defined as $\geqslant 110 \mathrm{mmgHg}$ with an increase of $\geqslant 15 \mathrm{mmHg}$ from baseline) were not noted at a statistically significantly increased rate between either study group and the placebo group. The mean increase in SBP in both active groups was $3.3 \mathrm{mmHg}$, compared to $0.1 \mathrm{mmHg}$ in the placebo group; the mean increase in DBP was $2.5 \mathrm{mmHg}$ in the $200 \mathrm{mg}$ /day group, $3.5 \mathrm{mmHg}$ in the $100 \mathrm{mg} /$ day group, and $0.4 \mathrm{mmHg}$ in the placebo group. 39 A clinically significant decrease in DBP was noted in $0.5 \%$ of patients taking either milnacipran $100 \mathrm{mg} /$ day or placebo; no clinically significant instances of a decrease in SBP were noted in any group.

A three-year, open-label, flexible dosing study was conducted to assess the safety and tolerability of long-term treatment with milnacipran. Patients were recruited following the completion of several other short-term studies and asked to complete a washout period of 2 weeks if they had been taking the study drug or any other prohibited medications during their previous study. Following washout, patients were all titrated up to a dose of $100 \mathrm{mg} /$ day milnacipran and kept at this dose for eight weeks; following the eight weeks, patients could decrease their dosage to a minimum of $50 \mathrm{mg} /$ day if they were unable to tolerate the higher dose, or increase their dose to a maximum of $200 \mathrm{mg}$ / day for improved symptom relief. ${ }^{35}$ Although this was primarily a study of safety and tolerability, clinical outcomes of improved fibromyalgia symptoms were collected as well, including daily and weekly pain recall, Patient Global Disease Status (PGDS), Patient Global Impression of Change (PGIC), and the Short-Form 36 Health Survey (SF-36). Of the 1227 patients enrolled, 585 completed the study; of those who discontinued, the majority $(256,40.0 \%$ of patients who discontinued, $20.9 \%$ of total patients) were due to adverse events, followed by withdrawal of consent (129, $20.0 \%$ of those who discontinued, $10.5 \%$ of total patients). ${ }^{35}$ $88.3 \%$ of total patients reported treatment-emergent adverse effects (TEAEs), most of which (89.5\%) were rated mild to moderate in severity by patients and judged to be unrelated to the study medication by the investigators. The study authors noted that the high incidence of TEAEs might be due to the extended period of time that the patients were in the study rather than due to $\mathrm{AE}$ of milnacipran. The most common ( $\geqslant 10 \%$ of patients) TEAEs were nausea (25.9\%), headache (13.4\%), hypertension (11.2\%), and sinusitis (10.4\%). Serious TEAEs were reported in $8.9 \%$ of patients, with the most common one being cholelithiasis, which occurred in 7 patients $(0.6 \%) .35$ There were no deaths reported during this study. Clinically significant increases in SBP (defined as $\geqslant 180 \mathrm{mmHg}$ with an increase of $\geqslant 20 \mathrm{mmHg}$ from baseline) occurred in $0.3 \%$ of patients, and clinically significant increases in DBP (defined as $\geqslant 110 \mathrm{mmHg}$ with an increase of $\geqslant 15 \mathrm{mmHg}$ from baseline) occurred in $1.1 \%$. Mean increases in SBP and DBP were $4.0 \mathrm{mmHg}$ and $3.3 \mathrm{mmHg}$, respectively. ${ }^{35}$ There did not appear to be any significant progressive increases in patients' blood pressures in this study and mean increases in blood pressure remained stable through the entire study period. Heart rate was also monitored and showed a $5.0 \mathrm{bpm}$ increase from baseline, with clinically significant increases (defined as $\geqslant 120 \mathrm{bpm}$ with an increase $\geqslant 20 \mathrm{bpm}$ ) in $0.4 \%$ of patients. Of the patients who completed the entire 3-year trial, $62.4 \%$ reported that their fibromyalgia symptoms were "much improved" or "very much improved" at the threemonth study visit, and $70.3 \%$ reported the same after the study. 35

In a data-mining analysis, Abtroun et al. set out to determine if the efficacy of milnacipran could be predicted by patient baseline and outcome variables. Data from three phase 3 clinical trials was pulled. Clustering analysis was run to determine patient symptom domains and efficacy outcome clusters. They then data-mined patients' baseline characteristics to analyze if certain clinical features could predict a significantly improved response milnacipran by patients. Data-mining was performed using Knowledge Extraction and Management (KEM), and a Ward hierarchical analysis was performed to determine natural clustering of patient outcomes and symptom domains. ${ }^{40}$ Outcome clusters of "pain and global," "mood and central status," and "function," which includes fatigue, were identified. The predictive data-mining analysis showed that "high pain intensity, low anxiety or catastrophizing level, absence of major sleeping problems, and physical limitations in the daily life effort" were all associated with substantially improved efficacy of milnacipran in patients. ${ }^{40}$ However, not all of the characteristics were predictive of improved efficacy for all 
doses - high pain intensity and low functional capabilities were found to be single baseline predictors for efficacy of milnacipran at $100 \mathrm{mg} /$ day, but not at $200 \mathrm{mg}$ /day. Further, the total number of baseline predictors decreases when the dose of milnacipran is increased from $100 \mathrm{mg} /$ day to $200 \mathrm{mg} /$ day, which suggests greater drug efficacy in the whole population at the higher dose. ${ }^{40}$

In a comparative meta-analysis study of milnacipran, amitriptyline, and duloxetine for treatment of fibromyalgia, study authors searched Cochrane Library, MEDLINE, SCOPUS, clinicalstudyresults.org, and clinicaltrials.gov. They found 19 total (10 amitriptyline, four duloxetine, and five milnacipran) randomized, placebo-controlled trials of the drugs in question. Using RevMan Analyses 5.0.24 and comprehensive meta-analysis software, they calculated standardized mean differences, number needed to treat, and indirect relative risks of amitriptyline vs. duloxetine, amitriptyline vs. milnacipran, and duloxetine vs. milnacipran. ${ }^{41}$ All three drugs were found to be superior to placebo to treat fibromyalgia symptoms, defined as pain, sleep disturbances, fatigue, and limitations of health-related quality of life (HRQOL). Amitriptyline was determined to be superior to duloxetine and milnacipran to reduce fibromyalgia symptoms in adjusted indirect comparisons. Duloxetine was found to be superior to milnacipran in reducing pain, sleep disturbances, and limitations of HRQOL, but milnacipran was determined to be superior to duloxetine in reducing fatigue. ${ }^{41}$ No significant differences were found in the total study dropout rates between the three drugs, which the authors use as a proxy for the acceptability of the drugs' adverse effects. In another comparative metaanalysis study, duloxetine, milnacipran, and pregabalin were compared. Study authors searched MEDLINE, SCOPUS, Cochrane Central Register of Controlled Trials, and looked for unpublished data from the FDA, US National Institutes of Health, and Industry through May 2009. Eighteen total studies meeting the criteria were identified; 13 were randomized controlled trials, and 5 were open-label extension studies. Data were analyzed using Winstat for Excel and RevMan Analyses 5.0 software, and the study authors followed the quality of reporting of meta-analyses (QUORUM) guidelines. Measures calculated were standardized mean differences, number needed to treat, number needed to harm, and adjusted indirect comparisons and indirect relative risks for each outcome for duloxetine vs. milnacipran, duloxetine vs. pregabalin, and milnacipran vs. pregabalin. Outcomes measured were reduction of pain, fatigue, sleep disturbance, depressed mood, and HRQOL. ${ }^{42}$ The three drugs reviewed were superior to placebo for all outcomes studied, with the exceptions of duloxetine for fatigue, milnacipran for sleep disturbance, and pregabalin for depressed mood, and all three were found to have similar efficacies in the short term ( $<6$ months). Duloxetine was found to be superior to both milnacipran and pregabalin in reducing depressed mood, and both duloxetine and pregabalin were superior to milnacipran for reducing pain and sleep disturbances. Milnacipran and pregabalin were superior to duloxetine in reducing fatigue. ${ }^{42}$ Risks associated with each drug were also analyzed, and both duloxetine and milnacipran were found to have a higher risk of nausea and headache than pregabalin. Duloxetine also had a higher risk of diarrhea compared to the other two medications. ${ }^{42}$ The study authors suggest taking the patient's symptomatology, comorbidities, and preferences and the drugs' side effect profiles under advisement when deciding which therapy will be most appropriate for the patient.

\section{CONCLUSION}

As seen with previous studies, milnacipran has been shown to improve FM symptoms by increasing neurotransmitter levels in descending central nervous system inhibitory pathways by inhibiting norepinephrine and serotonin reuptake. Long-term studies up to three years in duration found that milnacipran is effective for fibromyalgia symptoms. Milnacipran was also shown to be superior to duloxetine in reducing fatigue. The most common TEAEs were nausea, headache, hypertension, and sinusitis. Serious TEAEs were reported, with the most common one being cholelithiasis. Milnacipran carries a boxed warning for increased suicidal thinking and behavior in children, adolescents, and young adults and is not approved for use in pediatric patients. Before starting milnacipran, the patient's symptomatology, comorbidities, preferences, and the drugs' side effect profiles should be evaluated to determine whether milnacipran is appropriate for therapy.

With the continuation of the updated diagnostic classification system, the relationship between FM and contributing risk factors can be identified and lead to continuing research for future therapies. As mentioned, factors contributing to the pathophysiology of fibromyalgia include abnormalities in the central nervous system or neuroendocrine pathways, genetics, socioeconomic status, and psychological triggers. FM today continues to be a debilitating, chronic syndrome. Gaining further insight into risk factors that have clear links to FM may contribute to the development of preventative measures or therapies. Also, with advances in identifying pathophysiological factors of FM and connections between genetic components, the development of targeted and efficacious therapies to be used in conjunction with milnacipran may be a possibility in the future.

\section{DISCLOSURES}

The authors have nothing to disclose.

\section{FUNDING}

No external funding source was used for the generation of this publication.

Submitted: June 25, 2021 EST, Accepted: July 01, 2021 EST 
Table 1. Clinical Safety and Efficacy

\begin{tabular}{|c|c|c|c|}
\hline $\begin{array}{l}\text { Author } \\
\text { (Year) }\end{array}$ & Groups Studied and Intervention & Results and Findings & Conclusions \\
\hline $\begin{array}{l}\text { Mease } \\
\text { et al. } \\
(2009)^{39}\end{array}$ & $\begin{array}{l}888 \text { patients were treated with } \\
\text { either placebo ( } n=223) \text {, milnacipran } \\
100 \mathrm{mg} / \text { day }(n=224) \text {, or milnacipran } \\
200 \mathrm{mg} / \text { day }(n=441) \text {. Primary } \\
\text { efficacy measures for treatment of } \\
\text { fibromyalgia were defined as the } \\
\text { percentage of patients who met all } \\
\text { three of these criteria: } 1) \geq 30 \% \\
\text { improvement in pain from baseline, } \\
\text { assessed by daily patient recall, 2) a } \\
\text { rating of "very much improved" or } \\
\text { "much improved" on the Patient } \\
\text { Global Impression of Change } \\
\text { (PGIC), and 3) } \geq 6 \text { point } \\
\text { improvement from baseline in } \\
\text { physical function on the Medical } \\
\text { Outcome Study Short-From } 36 \\
\text { Physical Component Summary } \\
\text { (SF-36 PCS). Composite responder } \\
\text { rate was assessed at weeks } 15 \text { and } \\
27 .\end{array}$ & $\begin{array}{l}\text { At } 15 \text { weeks, a significantly higher number of } \\
\text { participants in the active arms ( } 200 \mathrm{mg} / \text { day, } \\
\mathrm{p}=0.017 ; 100 \mathrm{mg} / \text { day, } p=0.028) \text { met the criteria as } \\
\text { FM composite responders as compared to those in } \\
\text { the placebo arm. At } 27 \text { weeks, only the milnacipran } \\
200 \mathrm{mg} / \text { day arm showed a statistically significant } \\
\text { increase ( } p=0.034 \text { ) in FM pain composite } \\
\text { responders. PGIC scores were significantly } \\
\text { improved in both the } 100 \mathrm{mg} / \text { day and } 200 \mathrm{mg} / \text { day } \\
\text { milnacipran arms when compared to placebo at } \\
\text { week } 15 \text { ( } p=0.009, p<0.001 \text {, respectively), and } \\
\text { remained significant through week } 27 \text { ( } p<0.001) \text {. } \\
\text { Milnacipran was generally well-tolerated; only } \\
\text { nausea and palpitations caused study withdrawal } \\
\text { rates }>2 \% \text { and of greater incidence in the study } \\
\text { groups ( } 100 \mathrm{mg} / \text { day, } 32.6 \% ; 200 \mathrm{mg} / \text { day, } 40.1 \%) \\
\text { than in the placebo group }(21.1 \%) \text {. }\end{array}$ & $\begin{array}{l}\text { Milnacipran is } \\
\text { well tolerated } \\
\text { and significantly } \\
\text { more effective } \\
\text { than placebo in } \\
\text { the treatment of } \\
\text { fibromyalgia. }\end{array}$ \\
\hline $\begin{array}{l}\text { Arnold } \\
\text { et al. } \\
(2010)^{43}\end{array}$ & $\begin{array}{l}1025 \text { patients were randomized to } \\
\text { receive either placebo ( } n=509 \text { ) or } \\
\text { milnacipran } 50 \mathrm{mg} \text { BID ( } 100 \mathrm{mg} / \mathrm{day}) \\
(\mathrm{n}=516) \text {. Primary efficacy endpoints } \\
\text { were tested using } 2 \text { - and } 3 \text {-measure } \\
\text { composite responder analyses, } \\
\text { defined as: } 1 \text { ) } \geq 30 \% \text { improvement in } \\
\text { pain from baseline, assessed by } \\
\text { daily patient recall, } 2 \text { ) a rating of } \\
\text { "very much improved" or "much } \\
\text { improved" on the PGIC, and 3) } \geq 6 \\
\text { point improvement from baseline in } \\
\text { physical function on the SF-36 PCS. }\end{array}$ & $\begin{array}{l}\text { A significant improvement in pain scores was } \\
\text { noted by the authors in the treatment group } \\
\text { during the second week of dose escalation ( } 25 \mathrm{mg} \\
\text { BID) and maintained through the end of the } \\
12 \text {-week treatment period ( } p<0.001 \text { vs placebo). } \\
\text { Improvements in PGIC ratings in the treatment } \\
\text { arm were statistically significantly greater } \\
\text { ( } p<0.001 \text { vs placebo) at all clinic visits following } \\
\text { randomization. At week } 12 \text {, SF- } 36 \text { PCS scores in } \\
\text { the treatment group were significantly improved } \\
\text { compared to placebo ( } p<0.05 \text { ). Milnacipran also } \\
\text { significantly reduced fatigue ( } p=0.036 \text { ) and } \\
\text { depressive symptoms ( } p=0.008 \text { ) vs placebo. Any } \\
\text { TEAE was reported in } 75 \% \text { of placebo recipients } \\
\text { and } 84.1 \% \text { of milnacipran recipients. Nausea was } \\
\text { the most commonly reported AE (placebo, } 20.8 \% \text {; } \\
\text { milnacipran, 36.6\%). The only AE that led to study } \\
\text { discontinuation was more participants in the } \\
\text { treatment arm than in the placebo arm ( } 3.5 \% \text { and } \\
1.0 \% \text {, respectively). The proportion of participants } \\
\text { who experienced serious TEAEs was comparable } \\
\text { between study arms (milnacipran, } 1.6 \% \text {; placebo, } \\
1.2 \% \text { ). }\end{array}$ & $\begin{array}{l}\text { Milnacipran is } \\
\text { significantly } \\
\text { more effective } \\
\text { than placebo at } \\
\text { reducing FM- } \\
\text { related pain, } \\
\text { physical } \\
\text { symptoms, } \\
\text { fatigue, and } \\
\text { depression. It is } \\
\text { also well- } \\
\text { tolerated by } \\
\text { patients and } \\
\text { does not have a } \\
\text { significantly } \\
\text { increased risk of } \\
\text { serious AEs } \\
\text { compared to } \\
\text { placebo. }\end{array}$ \\
\hline $\begin{array}{l}\text { Arnold } \\
\text { et al. } \\
(2013)^{35}\end{array}$ & $\begin{array}{l}\text { 3-year, open-label, flexible-dosing } \\
\text { study of milnacipran involving } 1227 \\
\text { patients, } 47.7 \% \text { of whom were } \\
\text { classified as having completed the } \\
\text { study. The mean duration of } \\
\text { treatment was } 19 \text { months, and } \\
16.8 \% \text { of patients received } 36-38 \\
\text { months of treatment. }\end{array}$ & $\begin{array}{l}88.3 \% \text { of patients experienced } \geq 1 \text { TEAE, and } \\
20.9 \% \text { discontinued the study due to AEs. The } \\
\text { most common AEs were nausea ( } 25.9 \% \text { ) and } \\
\text { headache (13.4\%). Although this study was not } \\
\text { designed to analyze the efficacy of milnacipran, } \\
70.3 \% \text { of patients reaching the final study visit } \\
\text { rated their overall symptoms as "much improved" } \\
\text { or "very much improved," and long-term } \\
\text { improvements in SF-36 PCS ratings and Patient } \\
\text { Global Disease Status (PGDS) were also observed. }\end{array}$ & $\begin{array}{l}\text { Milnacipran } \\
\text { provides } \\
\text { sustained } \\
\text { symptom } \\
\text { improvement of } \\
\text { fibromyalgia up } \\
\text { to } 3.25 \text { years of } \\
\text { treatment and is } \\
\text { well-tolerated by } \\
\text { patients with } \\
\text { nausea and } \\
\text { headache as the } \\
\text { most common } \\
\text { AEs. }\end{array}$ \\
\hline $\begin{array}{l}\text { Periclou } \\
\text { et al. } \\
(2010)^{38}\end{array}$ & $\begin{array}{l}100 \text { healthy participants between } \\
\text { the ages of } 18 \text { and } 59 \text { (mean age } 33 \\
\text { years) were randomized to receive } \\
\text { either a single dose of placebo } \\
\text { followed by milnacipran titrated to } \\
\text { the supratherapeutic dose of } \\
300 \mathrm{mg} \text { BID over } 37 \text { days }(n=49 \text { ) or a } \\
\text { single dose of moxifloxacin } 400 \mathrm{mg}\end{array}$ & $\begin{array}{l}\text { Milnacipran 300mg BID increased participants' } \\
\text { heart rate a mean of } 23 \text { bpm, which resulted in a } \\
\text { shortening of the mean baseline-adjusted QT } \\
\text { interval. QTc also remained shortened in the } \\
\text { treatment group compared to placebo, and the } \\
\text { upper CI limit of milnacipran's effect on the } \\
\text { placebo- and baseline-adjusted QTc interval was } \\
\text { less than } 10 \mathrm{~ms} \text {. There were no participants in the }\end{array}$ & $\begin{array}{l}\text { Supratherapeutic } \\
\text { doses of } \\
\text { milnacipran do } \\
\text { not increase the } \\
\text { QTc interval of } \\
\text { healthy subjects } \\
\text { when corrected } \\
\text { for heart rate. }\end{array}$ \\
\hline
\end{tabular}




\begin{tabular}{|c|c|c|c|}
\hline & $\begin{array}{l}\text { followed by } 37 \text { days of placebo } \\
\text { ( } \mathrm{n}=51 \text { ). Three } 10 \text {-second ECG } \\
\text { recordings were taken } \\
\text { approximately } 2 \text { minutes apart for } \\
\text { all of the following time points: day } \\
-1 \text { (pre-dose [placebo in both } \\
\text { groups] and at } 1,1.5,2,2.5,3,4,5 \text {, } \\
6,8,10 \text {, and } 12 \text { hours after the } 8: 00 \\
\text { am dose), and days } 1 \text { and } 38 \text { (pre- } \\
\text { randomized dose and at } 1,2,2.5,3 \text {, } \\
4,6 \text {, and } 12 \text { hours after the } 8: 00 \text { am } \\
\text { dose). All ECGs were interpreted by } \\
\text { board-certified cardiologists who } \\
\text { were blinded to participant } \\
\text { information. }\end{array}$ & $\begin{array}{l}\text { milnacipran group with a QTc interval }>480 \mathrm{~ms} \text {, and } \\
\text { no participants in the treatment group had an } \\
\text { increase from baseline }>60 \mathrm{~ms} \text {. No other significant } \\
\text { changes to any cardiac parameter were noted in } \\
\text { either group. }\end{array}$ & \\
\hline $\begin{array}{l}\text { Trugman } \\
\text { et al. } \\
(2014)^{36}\end{array}$ & $\begin{array}{l}321 \text { fibromyalgia patients were } \\
\text { randomized to receive either } \\
\text { placebo or milnacipran in a dose- } \\
\text { escalation protocol (12.5 to 50mg/ } \\
\text { day over } 1 \text { week, } 50 \mathrm{mg} \text { BID for } 3 \\
\text { weeks, } 75 \mathrm{mg} \text { BID for } 1 \text { week, and } \\
100 \mathrm{mg} \text { BID for } 1 \text { week), followed by } \\
\text { a two-week discontinuation period. } \\
\text { Participants were asked to } \\
\text { discontinue the use of any other } \\
\text { medications for fibromyalgia and } \\
\text { centrally acting stimulants. Blood } \\
\text { pressure and heart rate were } \\
\text { assessed over } 24 \text { hours at baseline, } \\
\text { at the end of week } 4 \text { and week } 7 \\
\text { using an automated ABPM } \\
\text { machine. The primary outcome } \\
\text { parameter was a change from } \\
\text { baseline systolic blood pressure } \\
\text { (SBP) for the } 12 \text { hours following the } \\
\text { AM dose. Secondary parameters } \\
\text { were changes from baseline of } \\
\text { diastolic blood pressure (DBP), } \\
\text { mean SBP or DBP, and heart rate } \\
\text { (HR). }\end{array}$ & $\begin{array}{l}\text { Mean increases in SBP, DBP, and HR were found } \\
\text { with milnacipran at week four ( } 3.23 \mathrm{mmHg} \text {, } \\
3.81 \mathrm{mmHg}, 11.65 \mathrm{bpm} \text {, respectively) and week } \\
\text { seven ( } 4.17 \mathrm{mmHg}, 4.98 \mathrm{mmHg}, 14.01 \mathrm{bpm} \text {, } \\
\text { respectively). At week four, } 17.7 \% \text { of patients who } \\
\text { had been normotensive at baseline were } \\
\text { hypertensive, and at week seven, } 14.3 \% \text { of patients } \\
\text { were converted, compared to } 3.7 \% \text { and } 0.0 \% \text { of } \\
\text { patients treated with placebo, respectively. } \\
\text { Patients who were hypertensive at baseline } \\
\text { tended to have similar or lower mean increases in } \\
\text { BP and HR than normotensive patients - only two } \\
\text { patients in this cohort had any blood pressure } \\
\text { changes of clinical interest at week seven. } \\
\text { Additionally, the normal diurnal variation in BP } \\
\text { and HR were maintained in patients who received } \\
\text { milnacipran. After one week of the discontinuation } \\
\text { period, participants' BP and HR had not fully } \\
\text { returned to baseline. At the end of the two-week } \\
\text { washout, SBP had decreased } 27 \% \text {, mean DBP } \\
\text { decreased } 55 \% \text {, and HR decreased } 74 \% \text { from peak } \\
\text { changes during the trial period. }\end{array}$ & $\begin{array}{l}\text { Milnacipran does } \\
\text { cause an } \\
\text { increase in SBP, } \\
\text { DBP, and HR in } \\
\text { patients taking } \\
\text { therapeutic } \\
\text { doses. Changes } \\
\text { in normotensive } \\
\text { patients at } \\
\text { baseline are } \\
\text { more significant } \\
\text { than those who } \\
\text { are hypertensive } \\
\text { at baseline, and } \\
\text { all changes are } \\
\text { reversible when } \\
\text { the medication is } \\
\text { discontinued. }\end{array}$ \\
\hline
\end{tabular}


Table 2. Comparative Studies

\begin{tabular}{|c|c|c|c|}
\hline $\begin{array}{l}\text { Author } \\
\text { (Year) }\end{array}$ & Groups Studied and Intervention & Results and Findings & Conclusions \\
\hline $\begin{array}{l}\text { Häuser } \\
\text { et al. } \\
(2010)^{42}\end{array}$ & $\begin{array}{l}\text { Study authors searched MEDLINE, } \\
\text { SCOPUS, Cochrane Central Register of } \\
\text { Controlled Trials, and looked for } \\
\text { unpublished data from the FDA, US } \\
\text { National Institutes of Health, and } \\
\text { Industry through May 2009. } 18 \text { total } \\
\text { studies meeting the criteria were } \\
\text { identified; } 13 \text { were randomized } \\
\text { controlled trials, and } 5 \text { were open-label } \\
\text { extension studies. Data were analyzed } \\
\text { using Winstat for Excel and RevMan } \\
\text { Analyses } 5.0 \text { software, and the study } \\
\text { authors followed the quality of reporting } \\
\text { of meta-analyses (QUORUM) guidelines. } \\
\text { Measures calculated were standardized } \\
\text { mean differences, number needed to } \\
\text { treat, number needed to harm, and } \\
\text { adjusted indirect comparisons and } \\
\text { indirect relative risks for each outcome } \\
\text { for duloxetine vs. milnacipran, duloxetine } \\
\text { vs. pregabalin, and milnacipran vs. } \\
\text { pregabalin. Outcomes measured were } \\
\text { reducing pain, fatigue, sleep disturbance, } \\
\text { depressed mood, and health-related } \\
\text { quality of life (HRQOL). }\end{array}$ & $\begin{array}{l}\text { All studies reviewed showed } \\
\text { high methodological quality. } \\
\mathrm{I}^{2} \text {-statistics showed high } \\
\text { homogeneity in nearly all } \\
\text { outcomes of the studies. }\end{array}$ & $\begin{array}{l}\text { The three drugs reviewed } \\
\text { were superior to placebo for } \\
\text { all outcomes studied, with the } \\
\text { exceptions of duloxetine for } \\
\text { fatigue, milnacipran for sleep } \\
\text { disturbance, and pregabalin } \\
\text { for depressed mood, and all } \\
\text { three were found to have } \\
\text { similar efficacies in the short } \\
\text { term (<6 months). Duloxetine } \\
\text { was superior to both } \\
\text { milnacipran and pregabalin in } \\
\text { reducing depressed mood, and } \\
\text { both duloxetine and } \\
\text { pregabalin were superior to } \\
\text { milnacipran for reducing pain } \\
\text { and sleep disturbances. } \\
\text { Milnacipran and pregabalin } \\
\text { were superior to duloxetine in } \\
\text { reducing fatigue. Both } \\
\text { duloxetine and milnacipran } \\
\text { had a risk of nausea and } \\
\text { headache than pregabalin. } \\
\text { Duloxetine also had a higher } \\
\text { risk of diarrhea compared to } \\
\text { the other two medications. }\end{array}$ \\
\hline $\begin{array}{l}\text { Häuser } \\
\text { et al. } \\
(2011)^{41}\end{array}$ & $\begin{array}{l}\text { Study authors searched Cochrane } \\
\text { Library, MEDLINE, SCOPUS, } \\
\text { clinicalstudyresults.org, and } \\
\text { clinicaltrials.gov and found } 19 \text { total (10 } \\
\text { amitriptyline, } 4 \text { duloxetine, and } 5 \\
\text { milnacipran) randomized, placebo- } \\
\text { controlled trials of the drugs in question. } \\
\text { Using RevMan Analyses } 5.0 .24 \text { and } \\
\text { comprehensive meta-analysis software, } \\
\text { they calculated standardized mean } \\
\text { differences, number needed to treat, and } \\
\text { indirect relative risks of amitriptyline vs. } \\
\text { duloxetine, amitriptyline vs. milnacipran, } \\
\text { and duloxetine vs. milnacipran. Outcomes } \\
\text { measured were reducing pain, fatigue, } \\
\text { sleep disturbance, depressed mood, and } \\
\text { health-related quality of life (HRQOL). }\end{array}$ & $\begin{array}{l}\text { The reported methodological } \\
\text { quality of seven of the } \\
\text { amitriptyline studies was poor } \\
\text { and moderate in two studies. } \\
\text { The authors were not able to } \\
\text { get the missing details from the } \\
\text { study authors. The reported } \\
\text { methodological quality of three } \\
\text { duloxetine studies was low, and } \\
\text { one trial was moderate. The } \\
\text { reported quality of two } \\
\text { milnacipran studies was low, } \\
\text { two were moderate, and one } \\
\text { was high. However, after } \\
\text { receiving further details from } \\
\text { study authors, the } \\
\text { methodological quality of all } \\
\text { duloxetine and milnacipran } \\
\text { studies was high. I2 }{ }^{2} \text {-statistics } \\
\text { showed high heterogeneity in } \\
\text { pain and HRQOL outcomes } \\
\text { across the amitriptyline studies, } \\
\text { the HRQOL outcomes across } \\
\text { the duloxetine studies, and the } \\
\text { dropout outcomes in the } \\
\text { milnacipran studies. }\end{array}$ & $\begin{array}{l}\text { All three drugs were found to } \\
\text { be superior to placebo to treat } \\
\text { fibromyalgia symptoms, } \\
\text { defined as pain, sleep } \\
\text { disturbances, fatigue, and } \\
\text { limitations of HRQOL. } \\
\text { Amitriptyline was superior to } \\
\text { duloxetine and milnacipran for } \\
\text { the reduction of fibromyalgia. } \\
\text { Duloxetine was superior to } \\
\text { milnacipran in reducing pain, } \\
\text { sleep disturbances, and the } \\
\text { limitations of HRQOL. } \\
\text { Milnacipran was superior to } \\
\text { duloxetine in reducing fatigue. }\end{array}$ \\
\hline
\end{tabular}




\section{REFERENCES}

1. Perrot S. Fibromyalgia: A misconnection in a multiconnected world? Eur J Pain. 2019;23(5):866-873. doi:10.1002/ejp.1367

2. Arnold LM, Bennett RM, Crofford LJ, et al. AAPT Diagnostic Criteria for Fibromyalgia. J Pain. 2019;20(6):611-628. doi:10.1016/j.jpain.2018.10.008

3. Galvez-Sánchez CM, Duschek S, Del Paso GAR. Psychological impact of fibromyalgia: Current perspectives. Psychol Res Behav Manag. 2019;12:117-127. doi:10.2147/PRBM.S178240

4. Borchers AT, Gershwin ME. Fibromyalgia: A Critical and Comprehensive Review. Clin Rev Allergy Immunol. 2015;49(2):100-151. doi:10.1007/s12016-015-8509-4

5. Uçeyler N, Häuser W, Sommer C. A systematic review on the effectiveness of treatment with antidepressants in fibromyalgia syndrome. Arthritis Rheum. 2008;59(9):1279-1298. doi:10.1002/art.24000

6. Clauw DJ. Fibromyalgia: A clinical review. JAMA - J Am Med Assoc. 2014;311(15):1547-1555. doi:10.1001/j ama.2014.3266

7. Cabo-Meseguer A, Cerdá-Olmedo G, Trillo-Mata JL. Fibromyalgia: Prevalence, epidemiologic profiles and economic costs. Med Clin (Barc). 2017;149(10):441-448. doi:10.1016/i.medcli.2017.06.0 $\underline{08}$

8. Queiroz LP. Worldwide epidemiology of fibromyalgia topical collection on fibromyalgia. Curr Pain Headache Rep. 2013;17(8). doi:10.1007/s11916-0 13-0356-5

9. Verbunt JA, Pernot DHFM, Smeets RJEM. Disability and quality of life in patients with fibromyalgia.

Health Qual Life Outcomes. 2008;6:8. doi:10.1186/147 7-7525-6-8

10. Creed F. A review of the incidence and risk factors for fibromyalgia and chronic widespread pain in population-based studies. Pain.

2020;161(6):1169-1176. doi:10.1097/i.pain.000000000 $\underline{0001819}$

11. Imbierowicz K, Egle UT. Childhood adversities in patients with fibromyalgia and somatoform pain disorder. Eur J Pain. 2003;7(2):113-119. doi:10.1016/S 1090-3801(02)00072-1

12. Bradley LA. Pathophysiology of Fibromyalgia. Am J Med. 2009;122(12 SUPPL.). doi:10.1016/j.amjmed.20 09.09.008
13. Tzadok R, Ablin JN. Current and Emerging Pharmacotherapy for Fibromyalgia. Pain Res Manag. 2020;2020. doi:10.1155/2020/6541798

14. Chinn S, Caldwell W, Gritsenko K. Fibromyalgia Pathogenesis and Treatment Options Update. Curr Pain Headache Rep. 2016;20(4):25. doi:10.1007/s1191 6-016-0556-X

15. Häuser W, Bernardy K, Uçeyler N, Sommer C. Treatment of fibromyalgia syndrome with gabapentin and pregabalin--a meta-analysis of randomized controlled trials. Pain. 2009;145(1-2):69-81. doi:10.10 16/i.pain.2009.05.014

16. Häuser W, Urrútia G, Tort S, Üçeyler N, Walitt B. Serotonin and noradrenaline reuptake inhibitors (SNRIs) for fibromyalgia syndrome. Cochrane Database Syst Rev. 2013;2013(1). doi:10.1002/1465185 $\underline{8 . C D 010292}$

17. Julien N, Goffaux P, Arsenault P, Marchand S. Widespread pain in fibromyalgia is related to a deficit of endogenous pain inhibition. Pain. 2005;114(1-2):295-302. doi:10.1016/j.pain.2004.12.03 $\underline{2}$

18. Younger J, Mackey S. Fibromyalgia symptoms are reduced by low-dose naltrexone: a pilot study. Pain Med. 2009;10(4):663-672. doi:10.1111/j.1526-4637.20 $\underline{09.00613 . x}$

19. Younger J, Noor N, McCue R, Mackey S. Low-dose naltrexone for the treatment of fibromyalgia: findings of a small, randomized, double-blind, placebocontrolled, counterbalanced, crossover trial assessing daily pain levels. Arthritis Rheum. 2013;65(2):529-538. doi:10.1002/art.37734

20. Macfarlane GJ, Kronisch C, Dean LE, et al. EULAR revised recommendations for the management of fibromyalgia. Ann Rheum Dis. 2017;76(2):318-328. do i:10.1136/annrheumdis-2016-209724

21. Baron EP. Comprehensive Review of Medicinal Marijuana, Cannabinoids, and Therapeutic Implications in Medicine and Headache: What a Long Strange Trip It's Been .... Headache. 2015;55(6):885-916. doi:10.1111/head.12570

22. Distler O, Eich W, Dokoupilova E, et al. Evaluation of the efficacy and safety of terguride in patients with fibromyalgia syndrome: results of a twelve-week, multicenter, randomized, double-blind, placebocontrolled, parallel-group study. Arthritis Rheum. 2010;62(1):291-300. doi:10.1002/art.25062 
23. Sommer C, Häuser W, Alten R, et al. [Drug therapy of fibromyalgia syndrome. Systematic review, metaanalysis and guideline]. Schmerz. 2012;26(3):297-310. doi:10.1007/s00482-012-1172-2

24. Calandre EP, Rico-Villademoros F, Slim M. An update on pharmacotherapy for the treatment of fibromyalgia. Expert Opin Pharmacother. 2015;16(9):1347-1368. doi:10.1517/14656566.2015.10 $\underline{47343}$

25. Häuser W, Urrútia G, Tort S, Üçeyler N, Walitt B. Serotonin and noradrenaline reuptake inhibitors (SNRIs) for fibromyalgia syndrome. Cochrane Database Syst Rev. 2013;(1). doi:10.1002/14651858.CD $\underline{010292}$

26. Pharmaceuticals A, Limited I. Savella - Highlights of prescribing information. 2016;4(4):1-36. https://w ww.accessdata.fda.gov/drugsatfda_docs/label/2016/02 2256s022lbl.pdf

27. Mochizuki D, Hokonohara T, Kawasaki K, Miki N. Repeated administration of milnacipran induces rapid desensitization of somatodendritic 5-HT1A autoreceptors but not postsynaptic 5-HT1A receptors. J Psychopharmacol. 2002;16(3):253-260. doi:10.1177/0 26988110201600311

28. Pae CU, Marks DM, Shah M, et al. Milnacipran: beyond a role of antidepressant. Clin Neuropharmacol. 2009;32(6):355-363. doi:10.1097/WNF.0b013e3181ac $\underline{155 \mathrm{~b}}$

29. Maj J, Rogóz Z, Dlaboga D, DziedzickaWasylewska M. Pharmacological effects of milnacipran, a new antidepressant, given repeatedly on the alpha1-adrenergic and serotonergic 5-HT2A systems. J Neural Transm. 2000;107(11):1345-1359. d oi: $10.1007 / \mathrm{s} 007020070022$

30. Mongeau R, Weiss M, de Montigny C, Blier P. Effect of acute, short- and long-term milnacipran administration on rat locus coeruleus noradrenergic and dorsal raphe serotonergic neurons.

Neuropharmacology. 1998;37(7):905-918. doi:10.1016/ $\underline{\text { s0028-3908(98)00083-5 }}$

31. Puozzo C, Panconi E, Deprez D. Pharmacology and pharmacokinetics of milnacipran. Int Clin Psychopharmacol. 2002;17 Suppl 1:S25-35. doi:10.109 7/00004850-200206001-00004

32. Puozzo C, Leonard BE. Pharmacokinetics of milnacipran in comparison with other antidepressants. Int Clin Psychopharmacol. 1996;11 Suppl 4:15-27. doi:10.1097/00004850-199609004-000 $\underline{03}$
33. Puozzo C, Pozet N, Deprez D, Baille P, Ung HL, Zech P. Pharmacokinetics of milnacipran in renal impairment. Eur J Drug Metab Pharmacokinet. 1998;23(2):280-286. doi:10.1007/BF03189352

34. Puozzo C, Lens S, Reh C, et al. Lack of interaction of milnacipran with the cytochrome p450 isoenzymes frequently involved in the metabolism of antidepressants. Clin Psychopharmacol. 2005;44(9):977-988. doi:10.2165/00003088-20054409 $\underline{0-00007}$

35. Arnold LM, Palmer RH, Ma Y. A 3-Year, OpenLabel, Flexible-Dosing Study of Milnacipran for the Treatment of Fibromyalgia. Clin J Pain. 2013;29(12):1021-1028. doi:10.1097/AJP.0b013e31828 $\underline{440 \mathrm{ab}}$

36. Trugman JM, Palmer RH, Ma Y. Milnacipran effects on 24-hour ambulatory blood pressure and heart rate in fibromyalgia patients: A randomized, placebo-controlled, dose-escalation study. Curr Med Res Opin. 2014;30(4):589-597. doi:10.1185/0300799 5.2013.861812

37. Behlke LM, Lenze EJ, Carney RM. The Cardiovascular Effects of Newer Antidepressants in Older Adults and Those With or At High Risk for Cardiovascular Diseases. CNS Drugs. 2020;34(11):1133-1147. doi:10.1007/s40263-020-0076 $\underline{3-\mathrm{Z}}$

38. Periclou A, Palmer RH, Zheng H, Lindamood C. Effects of milnacipran on cardiac repolarization in healthy participants. J Clin Pharmacol. 2010;50(4):422-433. doi:10.1177/0091270009346059

39. Mease PJ, Clauw DJ, Gendreau RM, et al. The efficacy and safety of milnacipran for treatment of fibromyalgia. A randomized, double-blind, placebocontrolled trial. J Rheumatol. 2009;36(2):398-409. do i:10.3899/jrheum.080734

40. Abtroun L, Bunouf P, Gendreau RM, Vitton O. Is the efficacy of milnacipran in fibromyalgia predictable? A data-mining analysis of baseline and outcome variables. Clin J Pain. 2016;32(5):435-440. do i:10.1097/AJP.0000000000000284

41. Häuser W, Petzke F, Üeyler N, Sommer C. Comparative efficacy and acceptability of amitriptyline, duloxetine and milnacipran in fibromyalgia syndrome: A systematic review with meta-analysis. Rheumatology. 2011;50(3):532-543. do i:10.1093/rheumatology/keq354

42. Häuser W, Petzke F, Sommer C. Comparative Efficacy and Harms of Duloxetine, Milnacipran, and Pregabalin in Fibromyalgia Syndrome. J Pain. 2010;11(6):505-521. doi:10.1016/j.jpain.2010.01.002 
43. Arnold LM, Michael Gendreau R, Palmer RH, Gendreau JF, Wang Y. Efficacy and safety of milnacipran $100 \mathrm{mg} /$ day in patients with fibromyalgia: Results of a randomized, double-blind, placebo-controlled trial. Arthritis Rheum. 2010;62(9):2745-2756. doi:10.1002/art.27559 